\title{
Mikro Silika Dolgulu Yüksek Dayanımlı Betonun Mekanik Özelliklerine Ön Isıtmanın Etkisi
}

\author{
Ibrahim Alameri ${ }^{1 *}$, Meral Oltulu ${ }^{2}$, Metehan Ardahanl1 $^{3}$
}

Geliş / Received: 30/05/2020

Revize / Revised: 22/08/2020

Kabul / Accepted: 22/09/2020

$\overline{\mathbf{O Z Z}}$

Silis dumanı içeren betonun erken yaş sıcaklığı, silis dumanı yüzeyinin hızlı reaksiyon gösterme ve mukavemeti artırma eğilimi nedeniyle çok önemlidir. Kür metodu geçirimliliği, dayanımı ve durabiliteyi doğrudan etkiler. $\mathrm{Bu}$ çalışmada farklı oranlarda silis dumanı içeren betonların basınç dayanımı, eğilmede çekme dayanımı ve yarmada çekme dayanımı 2 kür metodunda araştırılmıştır. Basınç dayanımı için $15 \times 15 \times 15 \mathrm{~cm}$ küp numuneler, çekme deneyi için $10 \times 20 \mathrm{~cm}$ silindir numuneler ve eğilme dayanımı için $7 \times 7 \times 28 \mathrm{~cm}$ kiriş numuneler olmak üzere 3 farklı kalıp kullanılmıştır. Silis dumanı ağırlıkça çimento yerine mineral katkı olarak \%8, \%10, \%12 oranlarında kullanılmıştır. Deney için 2 grup hazırlanmış olup birinci grup 4 hafta su küründe iken ikinci grup ise 1 gün boyunca $75^{\circ} \mathrm{C}$ 'de ön 1 sıtma etkisinde ve sonrasInda 4 hafta su küründe tutulmuştur. Slump testi kullanılarak taze beton özellikleri araştırıldığında en yüksek slump değerinin ve basınç dayanımı, yarmada çekme dayanımı ve eğilmede çekme dayanımında da en iyi sonuçların \%10 silis dumanı içeren numunelerde olduğu görülmüştür.

1*Sorumlu yazar iletişim: i.ameri@eng-su.com(https://orcid.org/0000-0002-4921-3213)

Civil Eng. Dept., Ataturk University, Erzurum, Turkey

Civil Eng. Dept., Sana'a University, Sana'a, Yemen

2İletișim: mroltulu@atauni.edu.tr (https://orcid.org/0000-0002-3779-6888)

Civil Eng. Dept., Ataturk University, Erzurum, Turkey

3İletişim: metehan.ardahanli@erzurum.edu.tr (https://orcid.org/0000-0002-8091-2792)

Civil Eng. Dept., Erzurum Technical University, Erzurum, Turkey 


\title{
Influence of Preheating on the Mechanical Properties of High Strength Concrete with Micro Silica Filler
}

\begin{abstract}
The early-age temperature of concrete containing silica fume is very important due to the tendency of the silicafume surface to react quickly and increase strength. The curing method directly affects the permeability, strength, and durability of concrete. In this study, the effects of preheating on the compressive, splitting tensile and flexural tensile strengths of concrete with different ratios of silica fume were investigated. Three different mold type samples were used: $15 \times 15 \times 15 \mathrm{~cm}$ cube samples for the compression test, $10 \times 20 \mathrm{~cm}$ cylinder samples for the tensile test, and $7 \times 7 \times 28 \mathrm{~cm}$ beam samples for the bending tensile strength test. As a mineral additive, silica fume was replaced by $8 \%, 10 \%$, and $12 \%$ by weight of cement. Two groups were prepared for the test, group A was left in water for 4 weeks, group B was preheated for 1 day at $75^{\circ} \mathrm{C}$, and then left in water for 4 weeks. The results showed that the best addition of silica fume was $10 \%$, which increased workability and reduced the effect of early-age temperature.
\end{abstract}




\section{I.INTRODUCTION}

In the past few decades, structural and economic pressures to speed up construction project delivery have emphasized the need to estimate the early strength gain of concrete. Such a prediction is important for cold and hot weather conditions, and large concrete elements. In large concrete elements, the temperature gradient between the interior and the exterior surfaces is large and varies with age. Therefore, it is practically important to control the temperature at early ages to reduce crack formation caused by thermal shrinkage [1]. Curing temperature affects the early-age [2-5] and late-age strength of concrete [6,7]. Schachinger et al. [8] concluded that concrete subjected to $90^{\circ} \mathrm{C}$ early-age temperature for 24 to 48 hours caused an increase in the compressive strength. The reason for the increase in strength was mainly due to the pozzolanic reaction of silica fume with $\mathrm{Ca}(\mathrm{OH})_{2}$. Son and Hosoda [9] examined microcracks in concrete exposed to early-age temperatures of $5^{\circ} \mathrm{C}$ and $40^{\circ} \mathrm{C}$. The results showed that temperatures at an early-age caused higher strength concrete at early-ages, but eventually reached lower strength at late-ages. Kim et al. [10] studied concretes containing different types of cement and fly ash, cured in isothermal conditions up to $50^{\circ} \mathrm{C}$, and tested at different ages. They concluded that early-age temperature increased the compressive and tensile strengths at the early-age, but decreased the late-age compressive and splitting tensile strengths. Lin et al. [11] investigated the residual compressive strength of concrete cured in water after exposure to high temperatures. The findings of the study revealed that early-age temperatures significantly affected the residual strength.

The use of wastes, such as fly ash, silica fume, marble dust, and red mud from various industrial plants is widely used in concrete and cement technology. These wastes prevent environmental pollution and contribute positively to the economy and durability of concrete. [12-17].Adding silica fume to cement concrete increases the compressive strength and other mechanical properties of the concrete. These improvements are due to the closed packing achieved in the cement paste system, which reduces the total porosity and improves the interfacial transition zone [18]. Furthermore, the pozzolanic reaction with the calcium hydroxide crystals producing additional calcium-silicate-hydrate (C-S-H) and eliminating areas of stress concentrations and prone to failure initiation $\mathrm{Ca}(\mathrm{OH})_{2}$ crystals [11]. Based on the aforementioned advantages of adding silica fume to concrete, many studies have been conducted to evaluate the optimum ratio of silica fume in concrete. To produce a high strength concrete, silica fume was replaced by 5-20\% of cement weight [19]. Tohumcu and Bingöl [20] produced a selfcompacted concrete (SCC) using 5\%,10\% and $15 \%$ of silica fume, and $25 \%, 40 \%$ and $55 \%$ of fly ash. The results showed that the highest compressive strength was observed in concrete samples containing $15 \%$ silica fume. Demir [21] replaced silica fume and fly ash in concrete by 5, 10, 15, 20 and 25\%. The results showed that when $20 \%$ silica fume was added to concrete, the best compressive and tensile strength were obtained.

Successful addition of silica fume into cement composites will enhance the performance under preheating at early-ages. In this evaluation, silica fume particles were used as additives for a high strength cement concrete at different proportions. Two curing methods were applied. In the first group, the concrete was left in water for 4 weeks, while in the second group, concrete was subjected to a preheating temperature of $75^{\circ} \mathrm{C}$ for 1 day after that left in water for 4 weeks. The mechanical properties of the preheated cement concrete samples were thoroughly evaluated and compared to the first group. The mixing design, testing procedures, and test results are discussed in detail in the following sections.

\section{MATERIALS AND METHODS}

\section{A. Materials}

In this study, CEM II/A-M 42.5R ordinary Portland cement compliance with the Turkish standard TS EN 197-1 [22] and TS EN 196-1 [23]was used. These standards are compatible with European standards. The chemical and index properties cement and silica fume used are summarized in Table 1. To increase the workability of concrete a modified polycarboxylate superplasticizer was added to the mixture by $2 \%$ of the cement weight. The specific gravity of the aggregates was carried out in accordance with Turkish standard TS EN 1097-6 [24] and the results are summarized in Table 2. Figure 1 shows the granulometry of the aggregate used in this study. 


\begin{tabular}{|c|c|c|}
\hline & $\begin{array}{l}\text { BŞEÜ Fen Bilimleri Dergisi } \\
7(2), 1084-1093,2020\end{array}$ & $\begin{array}{r}\text { BSEU Journal of Science } \\
\text { DOI: } 10.35193 / \text { bseufbd.739609 }\end{array}$ \\
\hline & & 58-7575 (http://dergipark.gov.tr/bseufbd) \\
\hline
\end{tabular}

Table 1. Index and chemical properties of cement

\begin{tabular}{ccc}
\hline Chemical composition (\%) & CEM II/A-M 42.5R & Silica fume (SF) \\
\hline $\mathrm{SiO}_{2}$ & 17.60 & 88.8 \\
\hline $\mathrm{Al}_{2} \mathrm{O}_{3}$ & 4.45 & 0.17 \\
\hline $\mathrm{Fe}_{2} \mathrm{O}_{3}$ & 3.08 & 0.11 \\
\hline $\mathrm{CaO}$ & 60.02 & 1.01 \\
\hline $\mathrm{MgO}$ & 2.29 & 0.88 \\
\hline $\mathrm{SO}_{3}$ & 2.67 & 0.42 \\
\hline Loss on ignition & 8.49 & 2.40 \\
\hline $\mathrm{Na}_{2} \mathrm{O}$ & 0.22 & 0.19 \\
\hline $\mathrm{K}_{2} \mathrm{O}$ & 0.63 & 5.08 \\
\hline $\mathrm{Na}_{2} \mathrm{O}+0,658 \mathrm{~K}_{2} \mathrm{O}$ & 0.63 & - \\
\hline $\mathrm{Cl}$ & 0.01 & - \\
\hline Unmeasured & 0.54 & - \\
\hline Free CaO & 0.69 & - \\
\hline Total additives & 19.90 & \\
\hline Index properties & & 2.36 \\
\hline Specific gravity & 3.01 & 302 \\
\hline Specific surface $(\mathrm{cm} / \mathrm{g})$ & 4403 & - \\
\hline Compressive strength $(\mathrm{MPa})$ & 51.03 & \\
\hline
\end{tabular}

Table 2. Properties of aggregate

\begin{tabular}{cc}
\hline Aggregate size (mm) & Specific Gravity \\
\hline $0-2$ & 2.610 \\
\hline $2-4$ & 2.650 \\
\hline $4-8$ & 2.661 \\
\hline $8-16$ & 2.685 \\
\hline
\end{tabular}

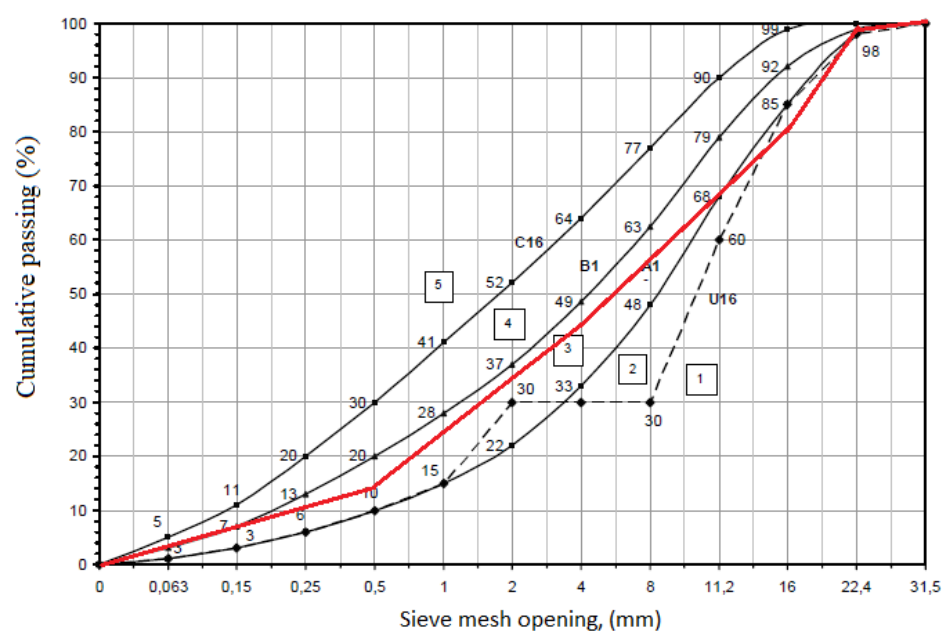

Figure 1. Aggregate granulometry

\section{B. Concrete Mix Design}

In this study, the concrete was designed according to the Turkish Standard TS EN 206 [25]. The samples were cast by replacing the cement weight with $8 \%, 10 \%$, and $12 \%$ silica fume. According to preliminary experimental works to produce a high strength concrete, the water/binder ratio was 0.276 and the water reducing additives superplasticizers was $2 \%$ by weight of cement. These ratios provided proper workability with minimum consistency. Three different mixing ratio groups were cast to produce $15 \times 15 \times 15 \mathrm{~cm}$ cube samples for compressive test, $10 \times 20 \mathrm{~cm}$ cylinder samples for splitting tensile test and $7 \times 7 \times 28 \mathrm{~cm}$ beam samples for flexural 
strength test. The mix ratios are summarized in Table 3 . The amount of aggregate, $\mathrm{W} / \mathrm{C}$ and superplasticizer ratios were kept constant because the quantity of silica fume added was slightly different.

Table 3. Concrete mix proportions

\begin{tabular}{|c|c|c|c|c|c|c|c|c|}
\hline \multirow{2}{*}{ Group } & \multirow{2}{*}{$\mathrm{C}$} & \multirow{2}{*}{ SF } & \multicolumn{4}{|c|}{ Aggregate } & \multirow{2}{*}{$\mathbf{W}$} & \multirow{2}{*}{ SP's } \\
\hline & & & $0-2(\mathrm{~mm})$ & $2-4(\mathrm{~mm})$ & 4-8 (mm) & 8-16 (mm) & & \\
\hline & $\mathrm{kg} / \mathrm{m}^{3}$ & $\mathrm{~kg} / \mathrm{m}^{3}$ & $\mathrm{~kg} / \mathrm{m}^{3}$ & $\mathrm{~kg} / \mathrm{m}^{3}$ & $\mathrm{~kg} / \mathrm{m}^{3}$ & $\mathrm{~kg} / \mathrm{m}^{3}$ & $\mathrm{~kg} / \mathrm{m}^{3}$ & $\begin{array}{c}(\%) \text { by weight } \\
\text { of cement }\end{array}$ \\
\hline SF $(8 \%)$ & 460 & 40 & 616 & 179 & 628 & 363 & 138 & 2 \\
\hline SF $(10 \%)$ & 450 & 50 & 616 & 179 & 627 & 362 & 138 & 2 \\
\hline SF $(12 \%)$ & 440 & 60 & 616 & 179 & 627 & 362 & 138 & 2 \\
\hline
\end{tabular}

\section{Experiments}

1.Concrete Slump Test: The concrete slump test is performed to determine the workability of fresh concrete, which is an important factor to find the consistency amount of water. In this study, the fresh concrete properties were made according to TS EN 12350-2 [26]. The slump values were measured using a standard slump cone apparatus.

2.Compressive, Splitting, And Flexural Tensile Tests: Compressive strength, splitting tensile and flexural tensile strength of samples were determined using ELE brand AUTOTEST with 300 tons capacity. The loading rates were $0.4 \mathrm{MPa} / \mathrm{s}, 0.02 \mathrm{MPa}$, and $0.04 \mathrm{MPa}$ for compressive strength, splitting tensile and flexural tensile strengths, respectively. This loading rate is within the range specified in TS 12390-3, TS EN 12390-6, and TS EN $12390-5$ [27-29].

\section{RESULTS AND DISCUSSION}

\section{A. Concrete Slump Test}

Chemical and mineral additives directly affect the properties of fresh concrete. In this study, superplasticizer as a chemical additive and silica fume as a mineral additive was used. Base on the preliminary experimental works to produce a high strength concrete, the water/binder ratio was 0.276 and the water reducing additives superplasticizers was $2 \%$ by weight of cement. These ratios provided proper workability with minimum consistency. The results of the slump test are listed in Table 4. All slump test values are in the range of $1-4 \mathrm{~cm}$ and indicate S1 class according to TS EN 12350-2 [26]. The slump of all groups was approximately the same with a small increase in groups containing $10 \%$ silica fume.

\section{B. Compressive Strength Test}

The compressive strength values of concrete are shown in Figure 2 and Table 4. In cure A, it was observed that the strength was inversely proportional to the amount of silica fume. This decrease in strength with the increase in the amount of silica fume may be explained due to the decrease in the amount of cement, which means that the $\mathrm{CH}$ formation in the concrete was reduced and produced less $\mathrm{C}-\mathrm{S}-\mathrm{H}$ gel despite pumice pozzolanic properties. On the other hand, curing B showed an increase in compressive strength as the amount of silica fume increased. The reason is that preheating at early ages accelerated the pozzolanic reaction of silica fume with $\mathrm{Ca}(\mathrm{OH})_{2}[30,31]$. Samples containing $12 \%$ silica fume preheated at an early age showed a $13 \%$ increase in compressive strength in comparison to normal curing. This indicates that the compressive strength of concrete can be increased by preheating at an early-age $[32,33]$. 
Table 4. Test results

\begin{tabular}{|c|c|c|c|c|c|c|c|}
\hline \multirow{2}{*}{ Group } & \multirow{2}{*}{ Slump (cm) } & \multicolumn{2}{|c|}{ Compressive strength (MPa) } & \multicolumn{2}{|c|}{ Splitting tensile strength (MPa) } & \multicolumn{2}{|c|}{ Flexural tensile strength $(\mathrm{MPa})$} \\
\hline & & Cure A & Cure B & Cure A & Cure B & Cure A & Cure B \\
\hline $8 \% \mathrm{SF}$ & 2.0 & 59.9 & 45.6 & 3.7 & 1.8 & 8.6 & 7.6 \\
\hline $10 \% \mathrm{SF}$ & 3.0 & 53.7 & 47.5 & 3.9 & 3.1 & 8.2 & 8.9 \\
\hline $12 \% \mathrm{SF}$ & 2.0 & 45.1 & 50.8 & 3.7 & 2.5 & 7.0 & 6.0 \\
\hline
\end{tabular}

Cure A: Placed in water for 4 weeks.

Cure B: Placed in the oven at $75 \mathrm{C}^{\circ}$ for 1 day then in water for 4 weeks

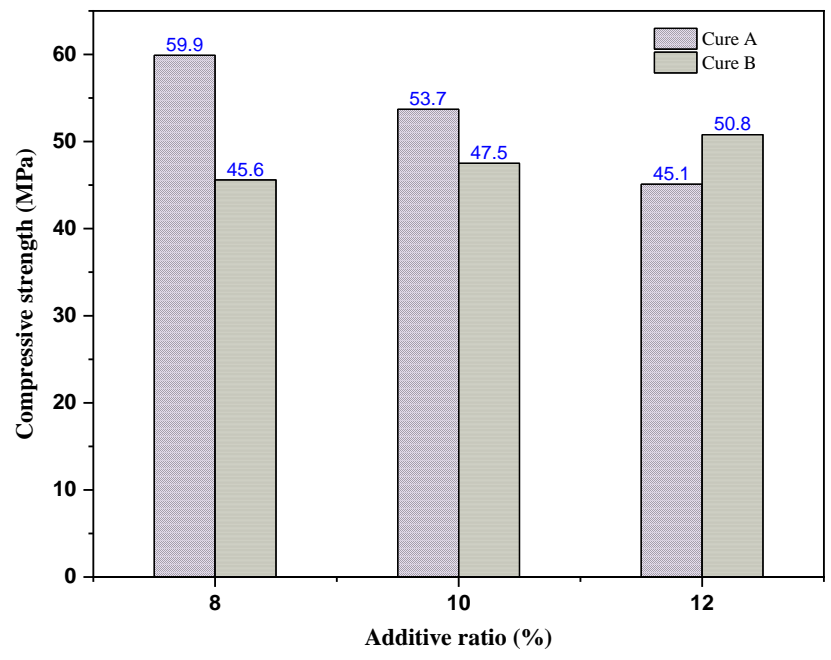

Figure 2. Compressive strength results

\section{Splitting Tensile Test}

According to the splitting tensile test results shown in Figure 3 and Table 4, the highest splitting tensile strength was obtained at $10 \%$ silica fume for both curing conditions. The increase in the splitting tensile in this ratio was because of the increase in the slump value. Concrete with high slump value indicates a more compact matrix with fewer amounts of voids. Adding more than $10 \%$ silica fume reduced the amount of cement that caused the reduction of $\mathrm{CH}$ formation in concrete and thus produced less $\mathrm{C}-\mathrm{S}-\mathrm{H}$ gels, despite having pozzolanic properties.

The results showed that the cure A samples were higher than cure B. This demonstrated that the curing condition clearly affected the strength of concrete. In comparison to the cure A samples, the cure B samples containing $8 \%, 10 \%$ and $12 \%$ silica fume showed a reduction in splitting tensile strength of $51.4 \%, 20.5 \%$, and $32.4 \%$, respectively. The splitting tensile strength results showed that under both curing conditions, the best proportion was $10 \%$ silica fume. These results were the same as the compressive strength results. The increase in splitting tensile at this ratio may be explained by the fact that pumice exhibits more pozzolanic activity in late curing ages and reacts with $\mathrm{CH}$ formed as a result of hydration of cement to form new $\mathrm{C}-\mathrm{S}-\mathrm{H}$ gels. 


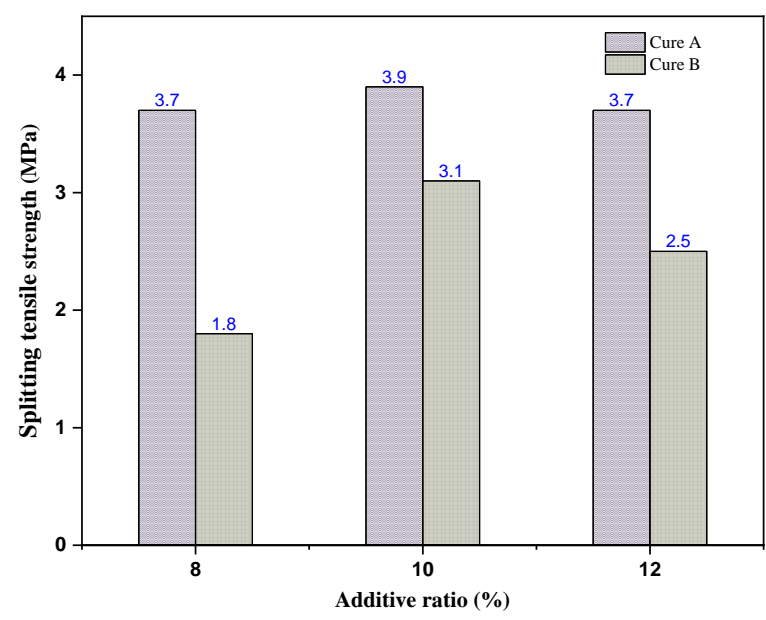

Figure 3. Splitting tensile results

\section{Flexural Tensile Test}

Figure 4 and Table 4 show the flexural tensile test results for both cure A and cure B. The results showed that the flexural tensile strength was inversely proportional to the additive ratios in the cure A samples. On the other hand, in cure B samples, the highest strength was seen in concrete containing $10 \%$ silica fume. The strength of $10 \%$ silica fume was maximum for both cure A and cure B. Also, at this rate cure B showed a clear increase in strength, even more than cure A. This result shows that the flexural strength of concrete containing silica fume can be increased by preheating the concrete at an early age.

The increase in the performance of concrete containing $10 \%$ silica fume was convenient with the results obtained in compressive and splitting tensile strength tests. Moreover, as mentioned before, the increase in the flexural tensile for samples containing $10 \%$ silica fume can be explained by the high slump value, which means fewer voids, and the pozzolanic activity in advanced curing ages which reacts with $\mathrm{CH}$ formed as a result of hydration of cement to form new C-S-H gels. Nevertheless, in the high additive ratios a decrease was observed because of the decrease in cement amount, $\mathrm{CH}$ formation in concrete decreased and thus pumice produced less $\mathrm{C}$ $\mathrm{S}-\mathrm{H}$ gel despite having pozzolanic property.

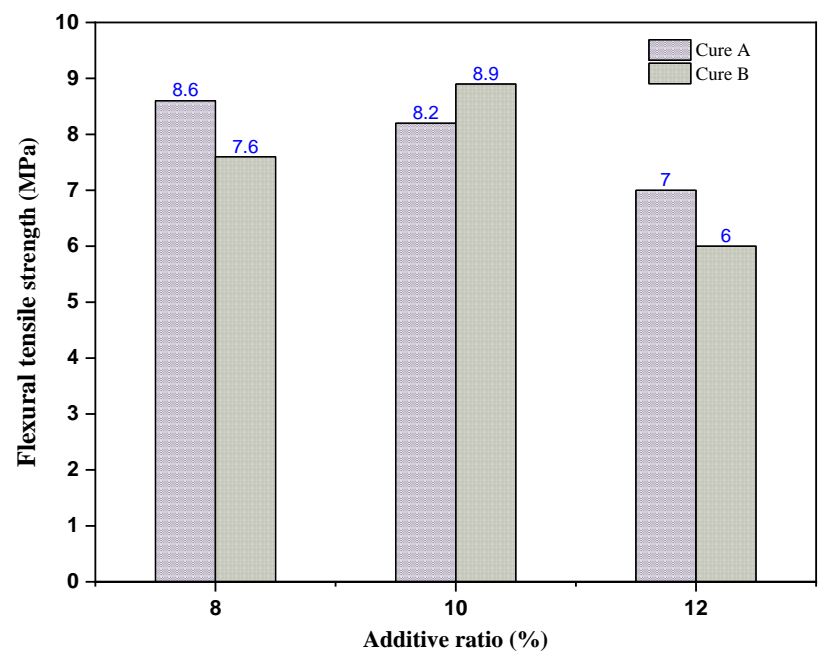

Figure 4. Flexural tensile results 


\section{CONCLUSION}

This present study compared the effect of the curing method for concrete containing silica fume on the basis of compressive, splitting tensile, and flexural tensile tests. Based on the results of this study, the following conclusions were reached:

$>$ The slump of all groups was approximately the same with a little increase in groups containing $10 \%$ silica fume.

$>$ Addition of silica fume to concrete decreased the compressive strength of concrete in curing A samples, while in samples subjected to preheating temperature (curing B) at an early age, the compressive strength increased as the amount of silica fume increased.

$>$ Samples containing $12 \%$ silica fume, when subjected to preheating temperature (cure B) at an early age, showed much higher compressive strength values than water cured (cure A).

$>$ The highest tensile and flexural strength was obtained at $10 \%$ silica fume for both curing conditions.

Further recommended studies include:

- The durability properties such as freeze-thaw, chemical attack, and abrasion of the concrete containing silica fume exposed to early-age temperature,

- $\quad$ Detailed microstructural and pore structure studies are recommended on the subject (e.g. SEM, XRD and TGA) in order to determine the mechanism by which silica fume acts, as a partial replacement when exposed to preheating temperatures,

- Different curing methods with different temperatures besides different pozzolanic materials,

- The effect of silica fume on concrete exposed to high temperatures at late-ages.

\section{REFERENCES}

[1] Kim, J.K., Moon, Y.H., \& Eo, S.-H. (1998). Compressive strength development of concrete with different curing time and temperature. Cement and Concrete Research, 28(12), 1761-1773.

[2] Husem, M., \& Gozutok, S. (2005). The effects of low temperature curing on the compressive strength of ordinary and high performance concrete. Construction and Building Materials, 19(1), 49-53. https://doi.org/10.1016/j.conbuildmat.2004.04.033

[3] Park, J.S., Kim, Y. J., Cho, J.-R., \& Jeon, S.-J. (2015). Early-Age Strength of Ultra-High Performance Concrete in Various Curing Conditions. Materials, 8(8), 5537-5553. https://doi.org/10.3390/ma8085261

[4] Pichler, Ch., Schmid, M., Traxl, R., \& Lackner, R. (2017). Influence of curing temperature dependent microstructure on early-age concrete strength development. Cement and Concrete Research, 102, 48-59. https://doi.org/10.1016/j.cemconres.2017.08.022

[5] Yang, K.H., Mun, J.S., \& Cho, M.-S. (2015, June 4). Effect of Curing Temperature Histories on the Compressive Strength Development of High-Strength Concrete [Research Article]. Advances in Materials Science and Engineering; Hindawi. https://doi.org/10.1155/2015/965471

[6] Singh, H. (2020). Effect of Curing on The Compressive Strength of High Strength Concrete. International Journal of Advanced Science and Technology, 29(10s), 6019-6022.

[7] Tan, K., \& Gjorv, O. E. (1996). Performance of concrete under different curing conditions. Cement and Concrete Research, 26(3), 355-361. https://doi.org/10.1016/S0008-8846(96)85023-X 
[8] Schachinger, I., Hilbig, H., Stengel, T., \& Fehling, E. (2008). Effect of curing temperature at an early age on the long-term strength development of UHPC. In 2nd International Symposium on Ultra High Performance Concrete, 10, 205-213.

[9] Son, H. N., \& Hosoda, A. (2010). Detection of Microcracking in Concrete Subjected to Elevated Temperature at Very Early Age by Acoustic Emission. Journal of Advanced Concrete Technology, 8(2), 201-211.

[10] Kim, J. K., Han, S. H., \& Song, Y. C. (2002). Effect of temperature and aging on the mechanical properties of concrete: Part I. Experimental results. Cement and Concrete research,32(7),1087-1094.

[11] Lin, Y., Hsiao, C., Yang, H., \& Lin, Y. F. (2011). The effect of post-fire-curing on strength-velocity relationship for nondestructive assessment of fire-damaged concrete strength. Fire Safety Journal, 46(4), 178-185.

[12] Topçu, İ. B., \& Kaval, M. (2001). Betonda Silis Dumanı Kullanımının Ekonomik Analizi. Eskişehir Osmangazi Üniversitesi Mühendislik ve Mimarlık Fakültesi Dergisi, 14(1),18-31.

[13] Onuaguluchi, O., \& Panesar, D. K. (2014). Hardened properties of concrete mixtures containing pre-coated crumb rubber and silica fume. Journal of Cleaner Production, 82, 125-131.

[14] Oltulu, M., \& Alameri, I. (2019). The mechanical properties of concrete with red mud (Bauxite Residue) and nano- $\mathrm{Al}_{2} \mathrm{O}_{3}$ at high temperatures. Feb-Fresenius Environmental Bulletin, 28(6),4692-4701.

[15] Das, S. K., Singh, S. K., Mishra, J., \& Mustakim, S. M. (2020). Effect of Rice Husk Ash and Silica Fume as Strength-Enhancing Materials on Properties of Modern Concrete-A Comprehensive Review. In Emerging Trends in Civil Engineering, 253-266.

[16] Alameri, I., \& Oltulu, M. (2020). Mechanical properties of polymer composites reinforced by silica-based materials of various sizes. Applied Nanoscience. https://doi.org/10.1007/s13204-020-01516-6

[17] Alameri, I., \& Oltulu, M. (2019). The effect of high temperatures on the properties of hardened concrete with bauxite residue materials. MAS International Conference on Mathematics-Engineering-Natural \& Medical Sciences, Erzurum, Turkey.

[18] Constantinides, G. (2013). 2-Nanoscience and nanoengineering of cement-based materials. In F. PachecoTorgal, M. V. Diamanti, A. Nazari, \& C.G. Granqvist (Eds.), Nanotechnology in Eco-Efficient Construction (pp. 9-37a). Woodhead Publishing. https://doi.org/10.1533/9780857098832.1.7

[19] Şimşek, O., Dur, A., Yaprak H. (2004). Properties of mortars added silica fume and superplasticizer. Journal of Polytechnic, 7(2), 169-178.

[20] Tohumcu, İ., Bingöl A. F. (2013). Fresh concrete properties and compressive strength of self-compacting concretes with silica fume and fly ash. DEÜ mühendislik fakültesi Mühendislik bilimleri dergisi, 15(2),3144.

[21] Demir, İ. (2009). Aynı Oranlarda İkame Edilen Silis Dumanı ve Uçucu Külün Betonun Mekanik Özelliklerine Etkisi. Uluslararası Mühendislik Araştırma ve Geliştirme Dergisi, 1(2), 1-7.

[22] TS EN. (2002). 197-1, Turkish standard for cement-part 1: compositions and conformity criteria for common cements. Türk Standartları Enstitüsü. Ankara, Turkey.

[23] TS EN. (2005). 196-1, Methods of testing cement-Part 1: Determination of strength. Türk Standartları Enstitüsü, Ankara,Turkey.

[24] TS EN. (2002). 1097-6, Agregaların Mekanik ve Fiziksel Özellikleri İçin Deneyler Bölüm 6: Tane Yoğunluğu ve Su Emme Oranının Tayini. Türk Standartları Enstitüsü, Ankara, Turkey. 
[25] TS EN. (2017). TS EN 206, A1: Beton-Özellik, performans, imalât ve uygunluk. Türk Standardları Enstitüsü. Ankara, Turkey

[26] TS EN. (2019). 12350-2, Beton-Taze Beton Deneyleri-Bölüm 2: Çökme (Slamp) Deneyi. Türk Standartları Enstitüsü, Ankara, Turkey.

[27] TS EN. (2010). 12390-3, Beton-Sertleşmiş Beton Deneyleri-Bölüm 3: Deney Numunelerinin Basınç Dayanımını Tayini. Türk Standartları Enstitüsü, Ankara, Turkey.

[28] TS EN. (2010). 12390-6, Beton - Sertleşmiş beton deneyleri - Bölüm 6: Deney numunelerinin yarmada çekme dayanımının tayini. Türk Standartları Enstitüsü, Ankara, Turkey.

[29] TS EN (2019).12390-5, Beton - Sertleşmiş beton deneyleri - Bölüm 5: Deney numunelerinin eğilme dayanımının tayini. Türk Standartları Enstitüsü, Ankara, Turkey.

[30] Kwon, Y.-H., Kang, S.-H., Hong, S.-G., \& Moon, J. (2017). Acceleration of Intended Pozzolanic Reaction under Initial Thermal Treatment for Developing Cementless Fly Ash Based Mortar. Materials, 10(3). https://doi.org/10.3390/ma10030225

[31] Zhang, Z., Zhang, B., \& Yan, P. (2016). Hydration and microstructures of concrete containing raw or densified silica fume at different curing temperatures. Construction and Building Materials, 121, 483-490. https://doi.org/10.1016/j.conbuildmat.2016.06.014

[32] Ardahanl1 M, Oltulu M, Alameri I (2019). Evaluation of the mechanical properties of self-compacting concrete containing fly ash subjected to early-age temperature. Hoca Ahmet Yesevi 2. Uluslararas1 Bilimsel Araştırmalar Kongresi, Erzurum, Turkey.

[33] Alameri I, Oltulu M, Ardahanlı M (2019). Effect of early-age temperature on the behavior of concrete containing silica fume. 3rd International Conference on Advanced Engineering Technologies, Bayburt, Turkey. 